\title{
オゾン処理とオゾン/過酸化水素処理の 逐次処理による溶存有機物質除去
}

\author{
林 禾 $^{1}$. 茂庭 竹生 ${ }^{2}$ \\ ${ }^{1}$ 正会員 工修 東海大学工学研究科特定研究員（广259-1292 神奈川県平塚市北金目 1117） \\ E-mail : $\underline{\text { linhe@keyaki.cc. u-tokai.ac. jp }}$ \\ 2 正会員 工博 東海大学教授 工学部土木工学科（广259-1292 神奈川県平塚市北金目 1117)
}

\begin{abstract}
オゾン処理と促進酸化処理のそれぞれの特長を活かし，THM などの消毒副生成物前駆物質の除去と TOC の 低隇化を同時に実現する処理方法の開発を目指すため, 生物活性炭処理と組合せの 2 段処理システムを提案し, その処理効果について検討した，それにより，DOC，THM 前駆物質の除去に関して，オゾン処理と $\mathrm{O}_{3} / \mathrm{H}_{2} \mathrm{O}_{2}$ 処理では差があることが認められるため, 最適な組合せを検討することで, 処理効率を高められることが判明 した. また, 本研究の範囲内では, 前段処理にオゾン処理, 後段処理に $\mathrm{O}_{3} / \mathrm{H}_{2} \mathrm{O}_{2}$ 処理を行うのが, 最適な組合 せであることがわかった。
\end{abstract}

Key Words: ozone, AOP: advanced oxidation process, BAC: biologically assisted carbon, THM

\section{1.はじめに}

近年, 環境に放出される環境污染物質はますます 多種多様化している. 毎日 5 万種類以上の化学物質 が環境中に放出されているといわれている ${ }^{1)}$ 。これ らの物質は水道水源の污染や水域の生態系に悪影 響を与えることが懸念されている，そのため，飲料 水のみならず排水水質に対する法規制も順次強化 されつつあり, 水処理技術の一層の高度化が求めら れている. 平成 16 年 4 月には 11 年ぶりに水道水水 質基準が全面改訂され，より安全な水の供給が求め られるようになった.トリハロメタン（THM）に加 えて臭素酸, ホルムアルデヒドなどの新たな副生成 物をはじめ新たな健康りスクの高い物質への対応 を踏まえたものである.さらに, 有機物質の測定法 も過マンガン酸カリウム消費量から TOC に変更に なり,より明確な方法に改正された。

污濁の進んだ水域を除けば, 環境水中に生物分解 性有機物質はわずかしか存在せず，ほとんどは生物 に利用されないフミン質であることが知られてい る. 浄水処理では, この対策としてオゾン処理など の高度浄水処理が取り入れられているが,オゾンは 強力な酸化分解能力を持つとはいえ, THM 前駆物 質の除去や有機物質の無機化は, ある程度までしか 進行しないことが知られている ${ }^{2), 3)}$. また，新水質
基準で有機物質の測定法に指定された TOC の除去 は, 殆ど期待できないのが現状である. より安全で おいしい水の供給を目指すには, TOC 除去が期待で きる浄水システムを構築することが重要である.

そこで本研究では, オゾン単独処理 $\left(\mathrm{O}_{3}\right.$ 処理 $)$ と オゾン/過酸化水素処理 $\left(\mathrm{O}_{3} / \mathrm{H}_{2} \mathrm{O}_{2}\right)$ のそれぞれの特 長を活かし, THM などの消毒副生成物前駆物質の 除去と TOC の低減化を同時に実現する処理方法の 開発を目指した. プロセスは $\mathrm{O}_{3}$ 処理と $\mathrm{O}_{3} / \mathrm{H}_{2} \mathrm{O}_{2}$ 処 理の遂次処理とし, それぞれの処理での有機物質の 分解特性を明らかにし, 生物活性炭 (BAC) 処理を 組合せることにより, THM 前駆物質, TOC の除去 のより効率的な除去方法について検討した.

\section{2. 実験方法}

\section{（1）試料水の調整および前処理}

実験は, 水道原水中に存在するフミン質と比較的 性質が似ていると考えられる市販腐葉土を抽出源 として, $0.1 \mathrm{~N}$ の水酸化ナトリウムによって抽出した フルボ酸（pH 1.5 で可溶なものと定義した）を用い て原水とした. フルボ酸は超純水に添加し, 硫酸ア ルミニウムで凝集沈澱処理したものを供試水とし, $1 \mathrm{~N}-\mathrm{H}_{2} \mathrm{SO}_{4}$ または $1 \mathrm{~N}-\mathrm{NaOH}$ で $\mathrm{pH}$ 約 7 に調整した. 


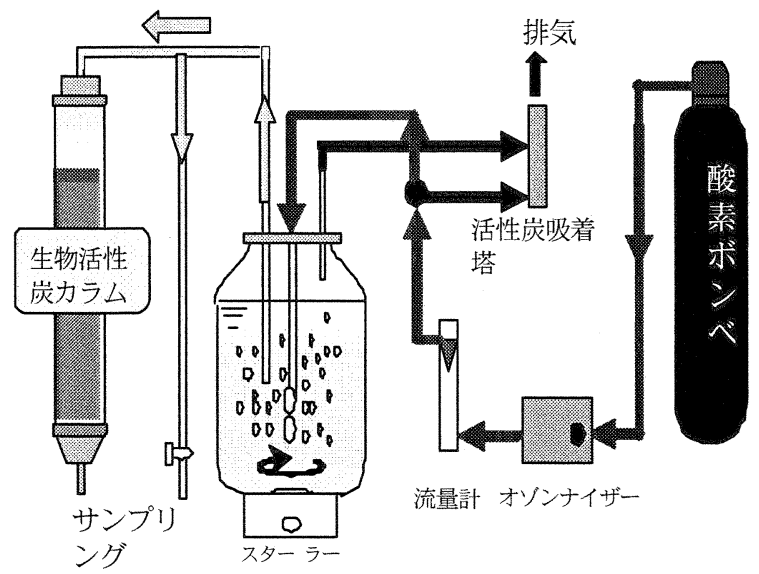

図-1 実験装置概略図

また，凝集剤の注入率は，予めジャーテストによ り処理後の DOC が最小となるところで決定した. ジャーテストは試料水の $\mathrm{pH}$ を 7 に調整後, 急速攪 挥 (回転数 $120 \mathrm{rpm}$ ) 5 分, 緩速攪汼 (回転数 $20 \mathrm{rpm}$ ) 10 分, 静置 30 分の条件で行った.

\section{（2）実験装置}

本研究に使用した実験装置の概要を図-1に示す. オゾン発生装置は POX-10(富士電機)を用い, 原料は 純酸素ガスである.

実験は, 反応槽の有効容量; $11 \mathrm{~L}$, 注入オゾン化 酸素風量; $1.0 \mathrm{NL} / \mathrm{min}$, 注入オゾン濃度; $2.6 \mathrm{~g} / \mathrm{Nm}^{3}$, 水温; $15 \sim 20^{\circ} \mathrm{C}$ 条件下で実施した.この条件で, pH 7 に調整した超純水中で溶存オゾン濃度を測定 すると, 最大で約 $2.0 \mathrm{mg} / \mathrm{L}$ となる. また, オゾン। 過酸化水素処理は, 過酸化水素の注入率は $5 \mathrm{mg} / \mathrm{L}$ とした.

実験に使用した活性炭は, 東京都玉川浄水場実験 施設で 1 年以上オゾン処理や $\mathrm{AOP}$ 処理後段の BAC 処理に用いたもの(Calgon 社製 Filtrsorb 400)である. 実験に使用したカラムは, 塩化ビニル製で内径 50 $\mathrm{mm}$, 高さ $1200 \mathrm{~mm}$ であり, 活性炭の層厚は $900 \mathrm{~mm}$ とし, 空筒接触時間 5 分とした. なお, 本実験ではす べて大学に供給される水道水を超純水装置 (オルガ ノ社製ピューリックーZ II）で精製した超純水を用い た.なお, 試薬は特に明示しない場合は和光純薬の ものを使用した.

\section{（3）分析方法}

サンプリングした試料について, 溶存オゾン濃度, E260, 溶存有機炭素(DOC), THMFP 及び三次元励起. 蛍光スペクトル（EEMS）を測定した。溶存オゾン 濃度の分析は, アシッドクロムバイオレット
$\mathrm{K}(\mathrm{ACVK})$ を用いた吸光光度法により測定した ${ }^{4)}$. $\mathrm{E} 260$ は波長 $260 \mathrm{~nm}$ における吸光度(島津製作所製 UV-2450)を光路長 $10 \mathrm{~mm}$ の石英セルを用いて測定 した。DOCは全有機炭素計（島津製作所, TOC-VCSH）で測定した.

トリハロメタン生成能の測定は, 試料水の量を 10 $\mathrm{mL}$ とし, 上水試験法(2001 年版)のヘッドスペース 法に従い，島津製作所製 GC-17A，QP5050A を用い た.

三次元励起·蛍光スペクトル（EEMS）は, キセノ ンランプを光源とした島津製作所製 RF-5300PC を 使用し， $1 \mathrm{~cm}$ 無蛍光セルを用い，スリット幅は励起 波長 $5 \mathrm{~nm}$, 蛍光波長 $5 \mathrm{~nm}$ で測定した.

また, DOC 組成の分画については, 西嶋ら ${ }^{5)}$ 方 法に基づいて, DOC を活性炭吸着性と生物分解性 に分画し, 吸着性のみを有する A-DOC, 吸着性と 生物分解性の両方をもつ AB-DOC, 生分解性のみ有 する B-DOC, そして, 吸着性も生物分解性も示さ ない NR-DOCの 4 種類に分画した.

\section{（4）実験内容と方法}

オゾンが, 有機物質を酸化分解する反応経路には, 次の 2 つがある.

(1)オゾンによる酸化

(2)ヒドロキシラジカル (OH ラジカル)による酸化

(1)は分子状オゾンによる直接酸化で, 物質に対し 選択的な反応であり, その強い酸化分解処理力に依 存し目的物質の除去が期待できる. 一方(2)は水中で オゾンが自己分解して生成した $\mathrm{OH}$ ラジカルによる 酸化でオゾンより酸化力が強く, また選択性がない ためあらゆる物質と反応することが知られている ${ }^{6}$.

$\mathrm{AOP}$ 処理はオゾンの自己分解による $\mathrm{OH}$ ラジカ ルの生成を促進し, 有機物質など目的物質の分解性 を高める処理方法である. 本研究で実施した実験は 次の 2 実験の組合せである.

実験 I : 溶存有機物質を生分解性と吸着性に分け $\tau, \mathrm{O}_{3}$ 処理と $\mathrm{O}_{3} / \mathrm{H}_{2} \mathrm{O}_{2}$ 処理により溶存有機物質が どのように変化するかを検討した. 腐葉土から抽出 したフルボ酸を用いて, 規定の DOC 濃度( 約 $14 \mathrm{mg} / \mathrm{L})$ に調整した供試水を, 粒状活性炭(Calgon 社 製 Filtrsorb 400)で循環吸着処理を行った. 3 日間後, DOC 濃度の減少はほとんどしないため, 残存した 活性炭除去できないDOC を NA-DOC と定義した (活性炭吸着除去できない部分)。一方, 同じ供試水 を砂 (300 ml の水中に大学近くの金目川から採取し た砂 $100 \mathrm{~g}$ )で, 一週間, $20^{\circ} \mathrm{C}$ の暗所で培養し, 生分 解性 DOC を除去し, 残存した DOC を NB-DOC と 定義した ${ }^{7)}$ (生物分解除去できない部分)。この分画 


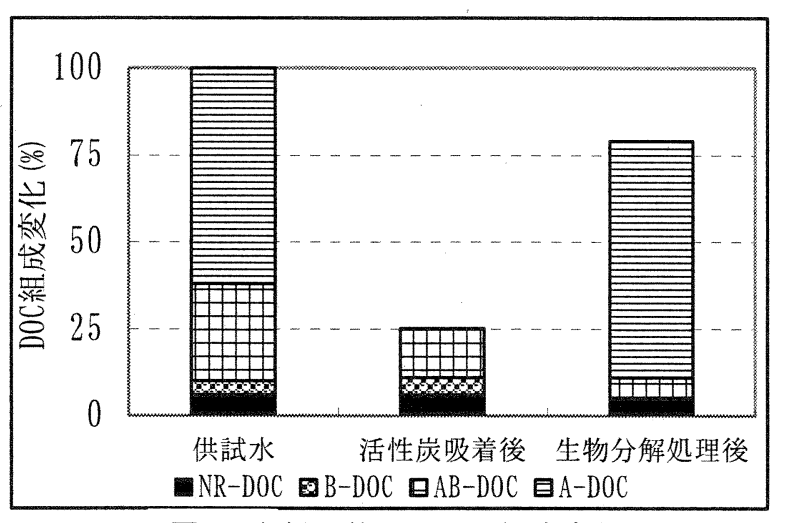

図-2 各処理後の DOC 組成変化

表-1 それぞれのプロセスにおける処理方法の組合せ

\begin{tabular}{|c|c|c|c|c|}
\hline & \multicolumn{2}{|c|}{ 前段処理 } & \multicolumn{2}{|c|}{ 後段処理 } \\
\hline Step I & 前酸化処理 & 活性炭処理 & 後酸化処理 & 活性炭処理 \\
\hline プロセス1 & $\mathrm{O}_{3}(5$ 分) & \multirow{9}{*}{ BAC I (5分) } & $\mathrm{O}_{3}(5$ 分) & \multirow{9}{*}{ 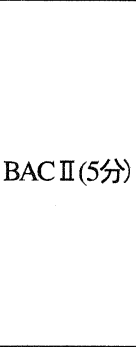 } \\
\hline プロセス2 & $\mathrm{O}_{3} / \mathrm{H}_{2} \mathrm{O}_{2}$ (5分) & & $\mathrm{O}_{2} / \mathrm{H}_{2} \mathrm{O}_{2}$ (5分) & \\
\hline プロセス3 & $\mathrm{O}_{3}$ (5分) & & $\mathrm{O}_{3} / \mathrm{H}_{2} \mathrm{O}_{2}$ (5分) & \\
\hline プロセス4 & $\mathrm{O}_{3} / \mathrm{H}_{6} \mathrm{O}_{2}(5$ 分) & & $\mathrm{O}_{3}(5$ 分) & \\
\hline Step II & 前酸化処理 & & 後酸化処理 & \\
\hline プロセス5 & $\mathrm{O}_{3}$ (7分) & & $\mathrm{O}_{3} / \mathrm{H}_{2} \mathrm{O}_{2}$ (3分) & \\
\hline プロセス6 & $\mathrm{O}_{3}(3$ 分） & & $\mathrm{O}_{3} / \mathrm{H}_{2} \mathrm{O}_{2}$ (7分) & \\
\hline プロセス7 & $\mathrm{O}_{3} / \mathrm{H}_{\mathrm{HO}}(7$ 分） & & $\mathrm{O}_{3}(3$ 分 $)$ & \\
\hline プロセス8 & $\mathrm{O}_{3} / \mathrm{H}_{2} \mathrm{O}_{2}$ (3分) & & $\mathrm{O}_{3}$ (7分） & \\
\hline
\end{tabular}

方法は簡便で分かりやすいが，一方では生物処理の 再現性が活性炭吸着よりも劣るため, 全体としての データの再現性, 信頼性が低くなる欠点がある.こ の時のD O Cの組成変化を図-2に示す.これらの試 料水を $\mathrm{O}_{3}$ 処理と $\mathrm{O}_{3} / \mathrm{H}_{2} \mathrm{O}_{2}$ 処理を行い, 有機物質の 組成変化について検討した。

実験 II: $\mathrm{O}_{3}$ 処理, $\mathrm{O}_{3} / \mathrm{H}_{2} \mathrm{O}_{2}$ 処理に加えて, BAC 処 理との組合せで溶存有機物質の除去効果について 検討した．実験内容は表-1 に示す通りである. Step $\mathrm{I}$ は前後段酸化処理として $\mathrm{O}_{3}$ 処理と $\mathrm{O}_{3} / \mathrm{H}_{2} \mathrm{O}_{2}$ 処理 の組合せについて，処理効果を比較した．Step IIは 前後段酸化処理の処理時間違いによる, 処理効果の 違いを比較した。

\section{3. 実験結果及び考察}

\section{(1) 実験 I}

\section{a) DOC の経時変化}

図-3にNA-DOCとNB-DOCについて， $\mathrm{O}_{3}$ 処理と $\mathrm{O}_{3} / \mathrm{H}_{2} \mathrm{O}_{2}$ 処理した場合の DOC 残存率の経時変化を 示す. NB-DOC を $\mathrm{O}_{3}$ 処理した場合, 処理開始 5 分程度までは, DOC 残存率はほとんど変化しない が，その後減少した。 これは開始後の 5 分はオゾン

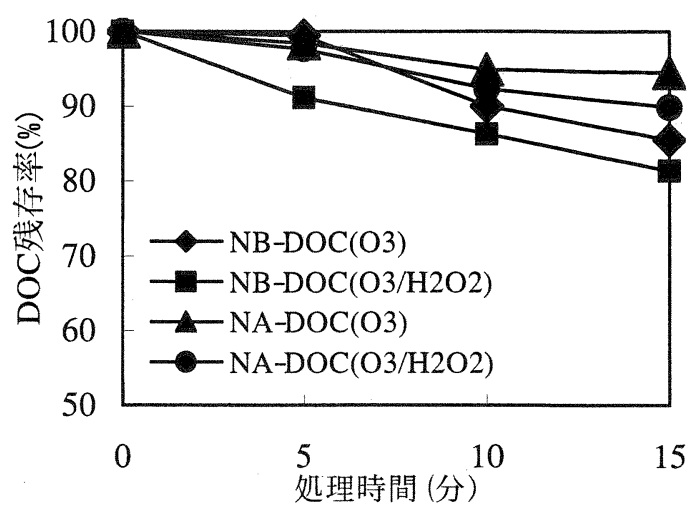

図-3 $\mathrm{O}_{3}$ と $\mathrm{O}_{3} / \mathrm{H}_{2} \mathrm{O}_{2}$ 処理における NA-DOC・ NB-DOC の DOC 残存率変化
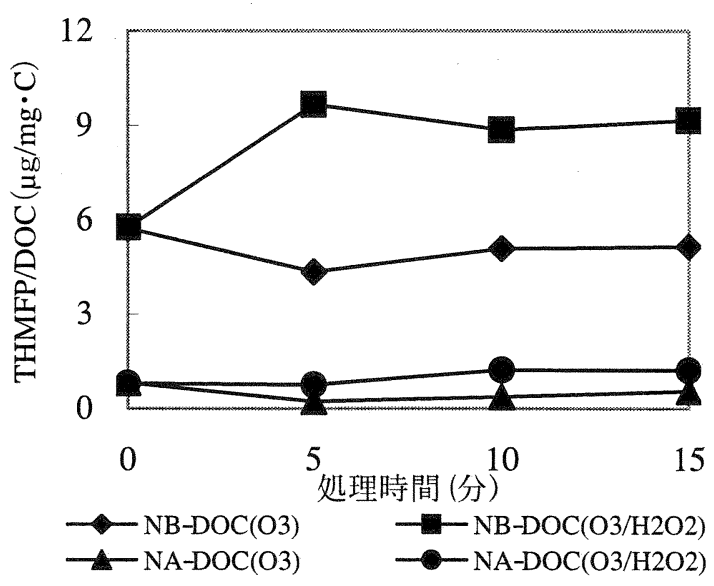

図-4 $\mathrm{O}_{3}$ と $\mathrm{O}_{3} / \mathrm{H}_{2} \mathrm{O}_{2}$ 処理における NA-DOC・ NB-DOC の THMFP/DOC の経時変化

による直接反応が主体であるが，それ以降は $\mathrm{OH}$ ラ ジカル反応が卓越し, 有機物質の無機化を進行させ ると考えられる.これに対し, $\mathrm{O}_{3} / \mathrm{H}_{2} \mathrm{O}_{2}$ 処理の場合 はDOC 残存率がほぼ直線的に減少し，15 分後には DOC 残存率は約 $80 \%$ にまで低下した。これは $\mathrm{O}_{3} / \mathrm{H}_{2} \mathrm{O}_{2}$ 処理ではオゾンの直接反応は生ぜず $\mathrm{OH}$ ラ ジカルのみによる酸化分解のためである. 一方, NA-DOC の場合は, 両処理とも処理時間 10 分経過 しても, 両者は顕著な差が認められなかった。しか し, 15 分後では $\mathrm{O}_{3} / \mathrm{H}_{2} \mathrm{O}_{2}$ 処理の方がやや残存率が低 くなった.このことから, OHラジカルは有機物質 の無機化に有効に㗢くことはよく知られているが、 特に NB-DOC の方が無機化が生じやすく, OH ラ ジカルが大きく寄与していることがわかる。

\section{b) THMFP/DOC の経時変化}

図-4 に THMFP/DOC の経時変化を示す. NB-DOC を $\mathrm{O}_{3}$ 処理した場合, THMFP/DOC は最初の 5 分間 で減少し, その後はほぼ一定值を示したのに対し， $\mathrm{O}_{3} / \mathrm{H}_{2} \mathrm{O}_{2}$ 処理では処理開始から 5 分後には, 初期值 $6 \mu \mathrm{g} / \mathrm{mgC}$ から約 $10 \mu \mathrm{g} / \mathrm{mgC}$ までに増加し, その 後はやや減少したが, 15 分後でも初期值より高い值 
なった。一方, NA-DOC では, $\mathrm{O}_{3}$ 処理では減少す るが, $\mathrm{O}_{3} / \mathrm{H}_{2} \mathrm{O}_{2}$ 処理では変化がなかった．しかし， THMFP/DOC は NB-DOC に比べ低く, THMFP に寄与する有機物質は主として NB-DOC であるこ とがわかる. THM 前駆物質は AOP によって, オゾ ン処理によりも THMFP が高くなるとの指摘がある が 8),99, 本研究の結果でも同様の結果が得られた.

また，NB-DOC が THMFP に大きく関係にしている ことから, 有機物質中の生物難分解性有機物質の除 去が THM 低減に重要であることが判明した.

c) NA-DOC 及び NB-DOC のオゾン処理, AOP 処 理後の DOC 組成比変化

图-5 は $\mathrm{O}_{3}$ 処理と $\mathrm{O}_{3} / \mathrm{H}_{2} \mathrm{O}_{2}$ 処理の DOC 組成比変化 を示す．供試水中の有機物質はフルボ酸であるた め, 生分解性は低く, 活性炭に対する吸着性の高 い有機物組成であることがわかる. NA-DOC は $\mathrm{O}_{3}$ 処理, $\mathrm{O}_{3} / \mathrm{H}_{2} \mathrm{O}_{2}$ 処理とも $\mathrm{AB}-\mathrm{DOC}$ の部分が減少し, $\mathrm{O}_{3}$ 処理では B-DOCに, $\mathrm{O}_{3} / \mathrm{H}_{2} \mathrm{O}_{2}$ 処理では一部が無 機化する一方 A-DOCに変化した. 図-3 で $\mathrm{O}_{3} / \mathrm{H}_{2} \mathrm{O}_{2}$ 処理で THMFPが上昇したのはA-DOCが増加した ことが関係していると考えられる.また， $\mathrm{O}_{3}$ 処理 で THMFPの減少がみられたのはB-DOCが増加し たことが原因であることから, THM 前駆物質と しては A-DOC の役割が大きく関与すると考えら れる.このことは, 例えば活性炭吸着処理が前駆 物質除去に有効な方法があることがわかる。一 方, NB-DOC は $\mathrm{O}_{3}$ 処理, $\mathrm{O}_{3} / \mathrm{H}_{2} \mathrm{O}_{2}$ 処理とも A-DOC は減少し, $\mathrm{AB}-\mathrm{DOC} に$ 変化した. また, $\mathrm{O}_{3}$ 処理に 比べ, $\mathrm{O}_{3} / \mathrm{H}_{2} \mathrm{O}_{2}$ 処理の方は A-DOC 減少が大きかっ た.このことから, $\mathrm{OH}$ ラジカルが DOC を無機化 する場合には，主に A-DOC，つまり生物により 分解出来ない有機物を無機化すると考えられる. 有機物質の吸着性, 生分解性は消毒副生成物制御 の観点から極めて重要な情報であることがわか る.

\section{d) 三次元励起蛍光分析による評価}

図-6に EEMS 分析結果を示す。原水は, 励起波 長 $325 \mathrm{~nm}$ /蛍光波長 $445 \mathrm{~nm}(\mathrm{P} 1)$, 同 $230 \mathrm{~nm} / 445$ $\mathrm{nm}(\mathrm{P} 2)$ に明確なピークが確認できる. また, 同 223 $\mathrm{nm} / 315 \mathrm{~nm}(\mathrm{P} 3)$ にも小さいピークの存在が認めら れた. Coble ${ }^{10)}$ は, フルボ酸様有機物が P1 及び P2 の蛍光発色団を有しているとしていることを示 しているが, 本結果でも同様であった.

图-7にNA-DOC と NB-DOCを含む供試水とそれ を $\mathrm{O}_{3}$ 処理と $\mathrm{O}_{3} / \mathrm{H}_{2} \mathrm{O}_{2}$ 処理した後の EEMS を示す. NA-DOC では, P3 は出現するが, P1, P2 が表わ れない. $\mathrm{O}_{3}$ 処理後は, ほんのわずかではあるがピ 一クが存在するのに対し, $\mathrm{O}_{3} / \mathrm{H}_{2} \mathrm{O}_{2}$ 処理後は, P3
は完全に消滅した。一方, NB-DOC では, P1, P2 は検出されるが, P3 は出現しない. また, $\mathrm{O}_{3}$ 処理 後, P1 は明らかに減少し, P2 も大幅に減少した. さらに, $\mathrm{O}_{3} / \mathrm{H}_{2} \mathrm{O}_{2}$ 処理後には, P1 は完全に消え, P2 は大幅に減少した。また，両処理とも，新らたな P3 を出現した.このピークの変化から, P1，P2 は NB-DOC, P3 は NA-DOC に強く関わっていること がわかる. NB-DOC は $\mathrm{O}_{3}$ 処理と $\mathrm{O}_{3} / \mathrm{H}_{2} \mathrm{O}_{2}$ 処理を受 けることにより, 一部の有機物質が生分解性に変化 するため, P3が新たに出現したものと考えられる. また, P1，P2 は活性炭吸着特性と示す有機物質特 有のピークと考えられるが $\mathrm{O}_{3}$ 処理では $\mathrm{P} 1, \mathrm{P} 2$ が共 に残り, $\mathrm{O}_{3} / \mathrm{H}_{2} \mathrm{O}_{2}$ 処理では, P1 は消滅し, P2 だけが
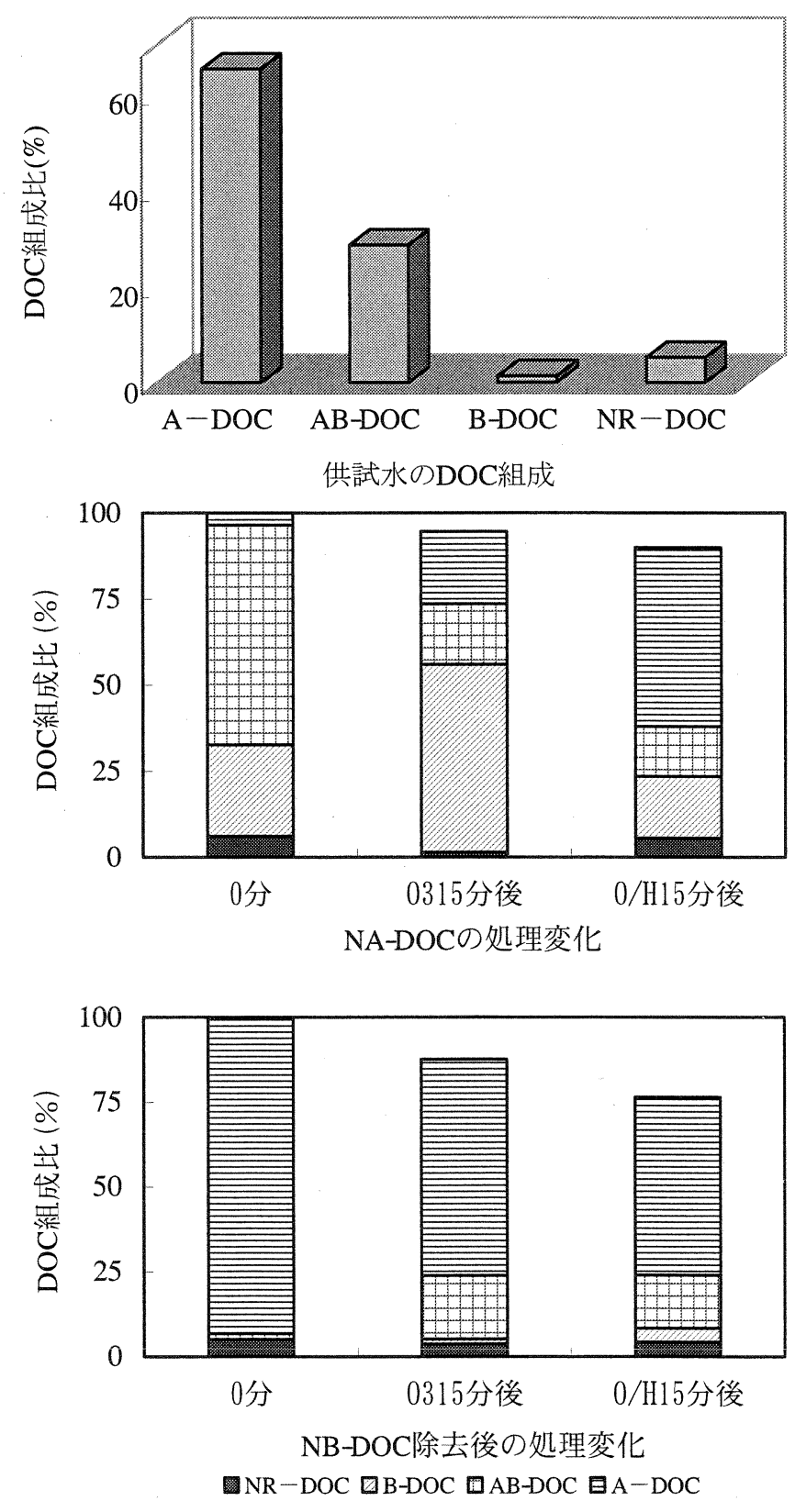

図-5 NA-DOC及びNB-DOCのオゾン処理・AOP処理後の DOC組成変化 注) $: \mathrm{O} / \mathrm{H}=\mathrm{O}_{3} / \mathrm{H}_{2} \mathrm{O}_{2}$ 
残存したことから, THM 前駆物質は P2 に大きく特 徵づけることができると考えられる. EEMS 分析は 有機物質の特徴をよく表現していることから, THM 前駆物質の評価に応用できるものを示唆した。

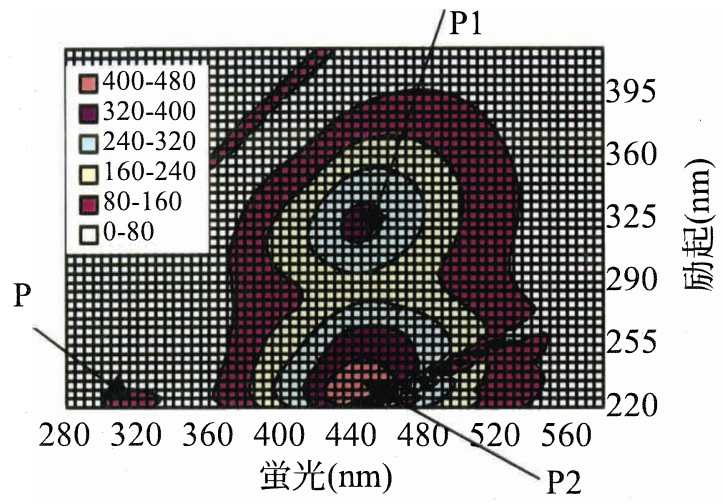

図-6 供試水のEEMS図
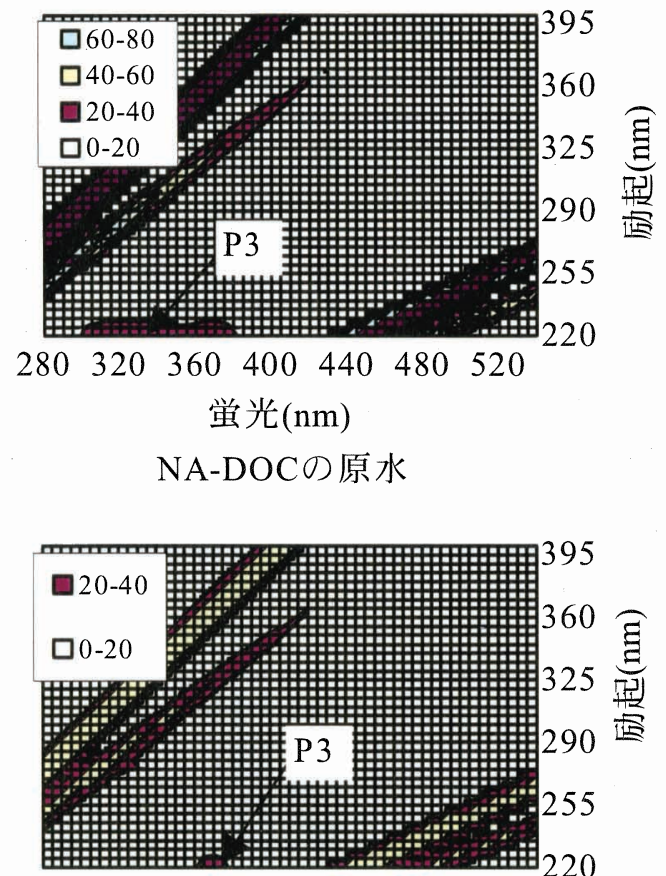

280320360400440480520 蛍光 $(\mathrm{nm})$

$\mathrm{NA}-\mathrm{DOC} の \mathrm{O}_{3}$ 処理 15 分

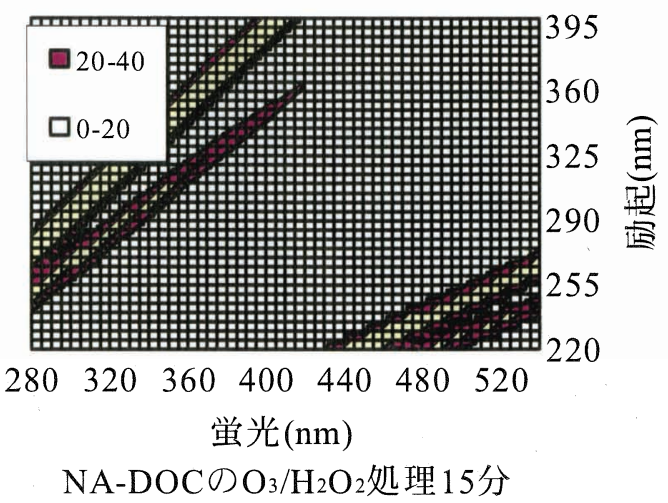

\section{（2）実験 II}

a) 1 段処理における DOC 残存率及び THMFP の 変化

図-8 は $\mathrm{O}_{3}$ 処理および $\mathrm{O}_{3} / \mathrm{H}_{2} \mathrm{O}_{2}$ 処理を 10 分間行い, その後 BAC 処理したときの DOC 残存率と THMFP の変化を示す. $\mathrm{O}_{3}$ 処理 10 分後, ほとんど DOC 低 下は認められないが, $\mathrm{O}_{3} / \mathrm{H}_{2} \mathrm{O}_{2}$ 処理では, $5 \%$ 程度の 無機化が認められた。 また, BAC 処理後はそれぞ れ $52 \% ， 45 \%$ に減少した. $\mathrm{O}_{3}$ 及び $\mathrm{O}_{3} / \mathrm{H}_{2} \mathrm{O}_{2}$ 処理と $\mathrm{BAC}$ 処理の組合せは DOC の除去に効果があり, $\mathrm{O}_{3}$ 処理よりも $\mathrm{O}_{3} / \mathrm{H}_{2} \mathrm{O}_{2}$ 処理の方がその効果が高いが, その除去率は 40 50\%程度あり, 高い DOC 除去率 を得ることは困難である。 また THMFP は $\mathrm{O}_{3}$ 処理 では, 処理に従い減少するのに対し, $\mathrm{O}_{3} / \mathrm{H}_{2} \mathrm{O}_{2}$ 処理 では一旦上昇し, BAC 処理後, $\mathrm{O}_{3}$ 処理とほぼ同等
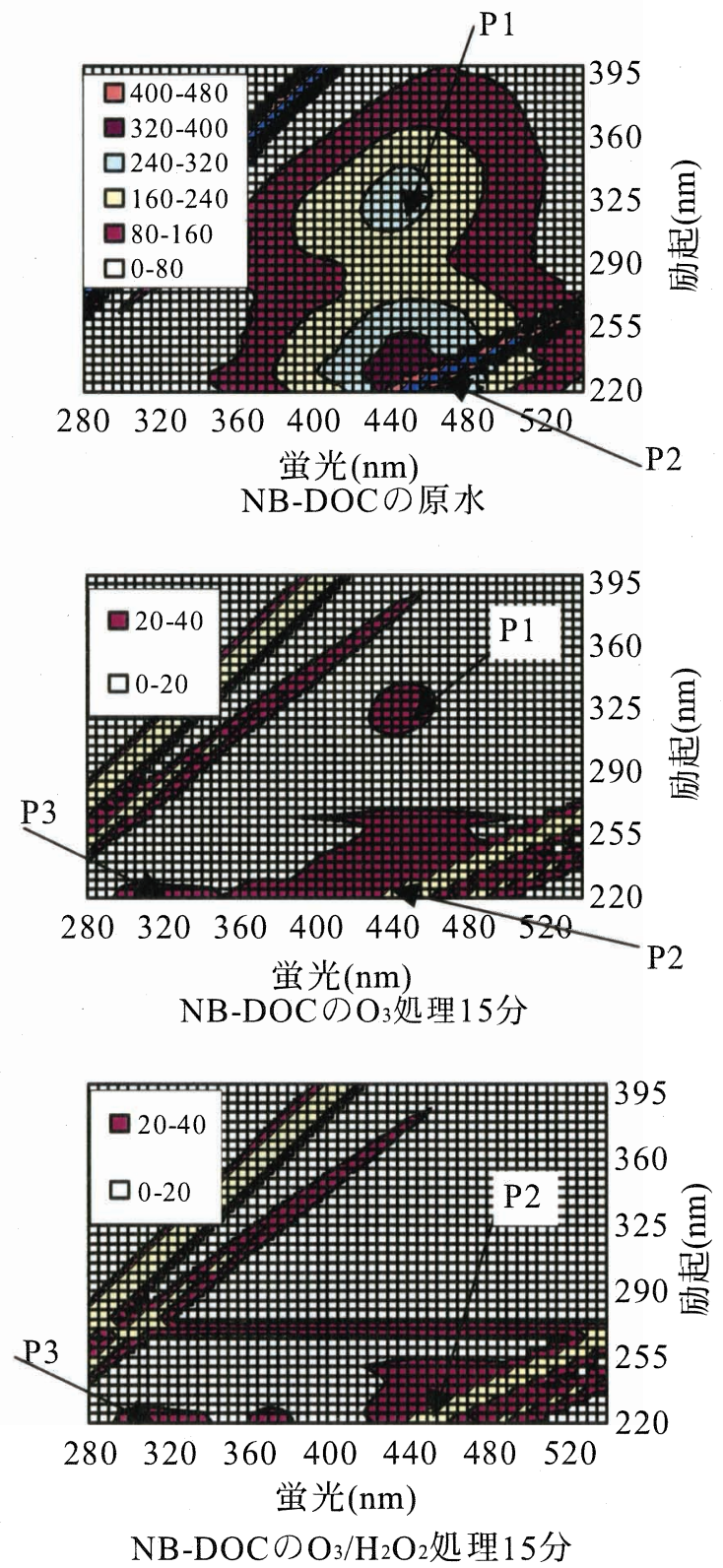

図-7 NA-DOC及びNB-DOCの $\mathrm{O}_{3}$ 処理・ $\mathrm{O}_{3} / \mathrm{H}_{2} \mathrm{O}_{2}$ 処理後のEEMSの比較 


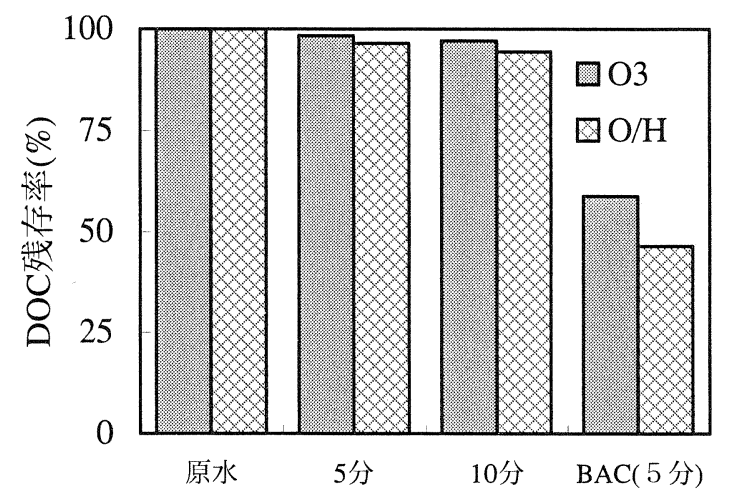

注）: $\mathrm{O} / \mathrm{H}=\mathrm{O} 3 / \mathrm{H} 2 \mathrm{O} 2$ 処理過程

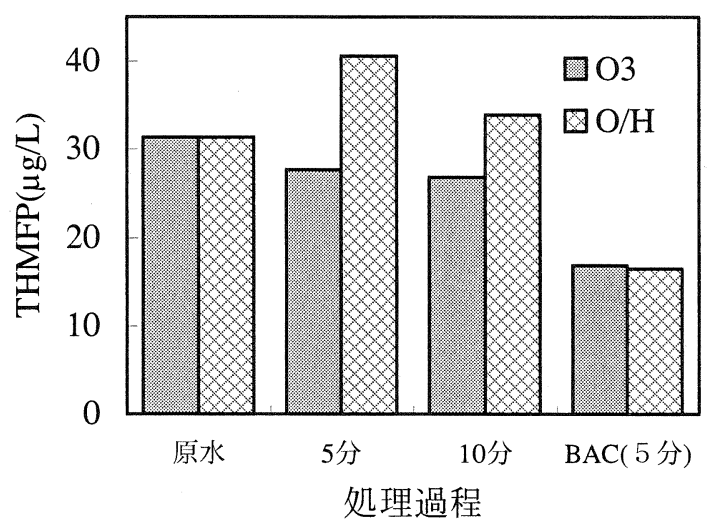

図-8 1 段処理におけるDOC 残存率および THMFP 変化

な值となることがわかった. $\mathrm{O}_{3}$ 単独処理の場合，才 ゾンの直接酸化とラジカル酸化が両方を作用する が, ラジカルの寄与はそれ程大きくない。一方 $\mathrm{O}_{3} / \mathrm{H}_{2} \mathrm{O}_{2}$ 処理は $\mathrm{H}_{2} \mathrm{O}_{2}$ がオゾンを分解するため, ラジ カル反応が主体となる，この酸化力は強いため, ベ ンゼン環を開環し, 有機酸を生成することが知られ ている ${ }^{3)}$. このため, 無機化も進行するが同時に塩 素化反応が生じ易い有機物質を作り出していると 考えられる.しかし，この画分は同時に生分解性を 有するため, $\mathrm{BAC}$ 処理後は $\mathrm{O}_{3}$ 処理とほぼ同等の THMFP となったと考えられる.いずれにしても， $\mathrm{O}_{3}$ の直接酸化と間接酸化力を有効に利用し, $\mathrm{O}_{3}$ 処 理と $\mathrm{O}_{3} / \mathrm{H}_{2} \mathrm{O}_{2}$ 処理を組合せると高効率での有機物質 除去が可能であると考えられる.

\section{b) プロセスの組合せ効果}

表-2 プロセス 1〜 4における DOC 残存率を示す. 各プロセスとも前酸化処理と BAC 処理で DOC 残存 率は47.3〜 53.3\%にまで減少したが，プロセス 1 は 最も残存率が高く, 以下プロセス 4 , プロセス 2 , プロセス 3 の順となった。また，前段酸化処理がオ ゾン処理の場合は, ほとんどDOCの低下はないが, $\mathrm{O}_{3} / \mathrm{H}_{2} \mathrm{O}_{2}$ 処理では $5 \%$ 程度の無機化が認められた。
表-2 各プロセスにおけるDOC残存率の変化（\%)

\begin{tabular}{|c|ccccc|}
\hline Step I & 原水 & 前酸化処理 & BAC I & 後酸化処理 & BAC II \\
\cline { 2 - 6 } プロセス1 & 100 & 99.2 & 53.3 & 51.4 & 38.9 \\
プロセス2 & 100 & 95.0 & 47.3 & 50.1 & 33.2 \\
プロセス3 & 100 & 98.9 & 51.2 & 45.8 & 23.5 \\
プロセス4 & 100 & 95.0 & 48.3 & 53.3 & 37.4 \\
\hline
\end{tabular}

表-3 各プロセスにおけるTHMFPの変化 $(\mu \mathrm{g} / \mathrm{L})$

\begin{tabular}{|c|c|c|c|c|c|}
\hline Step I & 原水 & 前酸化処理 & BAC I & 後酸化処理 & BAC II \\
\hline プロセス1 & 28. 2 & 24.3 & 17.5 & 19.8 & 14. 7 \\
\hline プロセス 2 & 31.7 & 40.7 & 27.5 & 23.8 & 16.0 \\
\hline プロセス3 & 29.6 & 23.4 & 16.8 & 26.7 & 12. 1 \\
\hline プロセス4 & 31.1 & 40. 0 & 17.5 & 13.6 & 12. 7 \\
\hline
\end{tabular}

一方, 前段処理では, $\mathrm{O}_{3} / \mathrm{H}_{2} \mathrm{O}_{2}$ 処理の方が有機物 質の無機化が進行するが，処理全体ではプロセス 3 の方が無機化進行した。このことから，前段を $\mathrm{O}_{3}$ 処理とし, 後段に $\mathrm{O}_{3} / \mathrm{H}_{2} \mathrm{O}_{2}$ 処理を用いた方が前段で の DOC の除去率は低くても，全体での除去率は高 く，効率的な組合せとなることが判明した。

表-3 に THMFP の変化を示す. プロセス 2 と 3 を比較すると, $\mathrm{O}_{3}$ 処理では THMFPが減少するが, $\mathrm{O}_{3} / \mathrm{H}_{2} \mathrm{O}_{2}$ 処理では逆に増加する傾向が認められた. これは他のプロセスについても同様である。しか し, $\mathrm{O}_{3} / \mathrm{H}_{2} \mathrm{O}_{2}$ 処理で THMFP が一旦上昇しても，後 段の $\mathrm{BAC}$ 処理はほぼ同等の值となっている。した がって，4 プロセスを比較すると前処理にはオゾン 処理を置く方が効率がよく, 有機物の無機化を考慮 すると, 後処理は $\mathrm{O}_{3} / \mathrm{H}_{2} \mathrm{O}_{2}$ 処理をすることが有効で あることが判明した

\section{c) 酸化処理時間の組合せ効果}

プロセスの組合せとしては DOC の除去率, THMFP の変化とも前酸化処理に $\mathrm{O}_{3}$ 処理, 後酸化処 理に $\mathrm{O}_{3} / \mathrm{H}_{2} \mathrm{O}_{2}$ 処理が効率的とわったので，その組合 せで処理時間を変化させて検討を行った。表-4は， 前段処理と後段処理時間を変化させた場合の DOC 残存率を示す. 結果を比較すると, 前酸化処理 7 分, 後酸化処理 3 分の場合は DOC 残存率が最も低く, 17.8\%までに低減した。 これに対し，比較のために 行ったプロセス 7 と 8 で前酸化処理に $\mathrm{O}_{3} / \mathrm{H}_{2} \mathrm{O}_{2}$ 処理 3 分, 後酸化処理にオゾン処理 7 分の組合せに比較 して，検討しても，プロセス 1〜4 で得られた結果 と同様に，前段を $\mathrm{O}_{3}$ 処理とした方が最も高い DOC 除去となった。 
表-4 前後酸化処理時間を変えたのDOC残存率変化 $(\%)$

\begin{tabular}{|c|ccccc|}
\hline Step I & 原水 & 前酸化処理 & $\mathrm{BAC} I$ & 後酸化処理 & BAC II \\
\cline { 2 - 6 } プロセス & 100 & 97.8 & 37.7 & 39.2 & 17.6 \\
プロセス6 & 100 & 98.2 & 49.4 & 47.7 & 21.3 \\
プロセス7 & 100 & 96.0 & 55.1 & 54.6 & 30.3 \\
プロセス8 & 100 & 97.2 & 47.9 & 48.3 & 26.2 \\
\hline
\end{tabular}

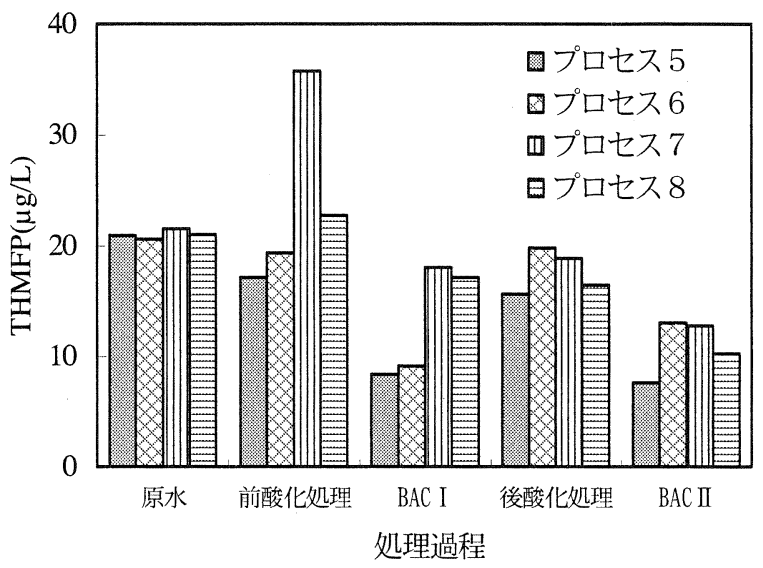

図-9＼cjkstart酸化処理時間の組み合わせにおけるTHMFPの変化

図-9 は前段処理と後段処理時間を変えた場合の THMFP の変化を示す. 4 プロセスの結果を比較す ると, プロセス 5 が最も THMFP が低く, $10 \mu \mathrm{g} / \mathrm{L}$ 以下までに低減した。従って, DOC, THM 前駆物 質の除去を目的として $\mathrm{O}_{3}$ 処理と $\mathrm{O}_{3} / \mathrm{H}_{2} \mathrm{O}_{2}$ 処理を行 う場合はその処理時間も影響をすることが判明し， この実験の範囲内では最適組合せとして, 前酸化 $\mathrm{O}_{3}$ 処理 7 分, 後酸化 $\mathrm{O}_{3} / \mathrm{H}_{2} \mathrm{O}_{2}$ 処理 3 分がより良い処 理効果が得られると判明した。

\section{d） 2 段処理における DOC 組成変化}

プロセス 1〜4 について検討した結果, DOCの除 去率, THMFP の変化ともに前酸化処理にオゾン処 理, 後酸化処理に $\mathrm{O}_{3} / \mathrm{H}_{2} \mathrm{O}_{2}$ 処理の組合せ (プロセス 3)が最適な組合せとなった.また処理時間を変化さ せた場合, 前酸化処理のオゾン処理 7 分, 後酸化処 理の $\mathrm{O}_{3} / \mathrm{H}_{2} \mathrm{O}_{2}$ 処理 3 分の組合せであるプロセス 5 が DOC 残存率を一番低下させる結果を得た。この組 合せで処理時間を変化させた場合 (プロセス $3,5,6$ ) 処理後のサンプルを DOC 組成の分画し ${ }^{5)}$ 、生物分 解性 DOC (B-DOC+AB-DOC), 吸着性 DOC $(\mathrm{A}-\mathrm{DOC}+\mathrm{AB}-\mathrm{DOC})$ の変化を検討した. 図-10にプロ セスごとの生物分解性, 吸着性 DOC とその除去率 を示した。前酸化処理の $\mathrm{O}_{3}$ 処理後では処理時間の 違いによらず生物分解性, 吸着性 DOC とも除去率 が低く，差が見られないが，BAC I 処理後には前段 のオゾン処理 7 分の場合が生物分解性
DOC $(B-D O C+A B-D O C)$, 吸着性 DOC (A-DOC+ AB-DOC）の除去率が高くなる傾向を示し，前段の オゾン処理時間の長い方がより効率的に除去でき ることが確認出来た。また, 後酸化処理, BACII処 理後でも同様な傾向が見られ，全体の処理時間と同 じにするのであれば前酸化処理の $\mathrm{O}_{3}$ 処理時間を長 くとった方が, BAC I での除去効率が増すことの効 果で, 処理全体としての DOC が低下するとの結果 が得られた。これはオゾン・BAC 処理で活性炭吸 着性有機物質の除去が進行するためで、オゾン処理 が有機物質の生物分解性を向上させる効果がある ためと考えられる。

\section{4. まとめ}

市販腐葉土から抽出したフルボ酸を用いた人工 原水を生分解性と活性炭吸着性に分画し, $\mathrm{O}_{3}$ 処理と $\mathrm{O}_{3} / \mathrm{H}_{2} \mathrm{O}_{2}$ 処理を行い, さらに $\mathrm{O}_{3}$ 処理, $\mathrm{O}_{3} / \mathrm{H}_{2} \mathrm{O}_{2}$ 処理 の他, $\mathrm{BAC}$ 処理との組合せによる実験を行った. そしてこのとき消毒副生成物前駆物質が $\mathrm{O}_{3}$ 処理や $\mathrm{O}_{3} / \mathrm{H}_{2} \mathrm{O}_{2}$ 処理また $\mathrm{BAC}$ 処理により, 有機物質の性質 がどのように変化するかについて検討した．その結 果，以下の知見が得られた.

1) 水中の有機物質中のうち活性炭吸着性を示 す DOC は THM の生成に強く関わっている. このことから，吸着性 DOC を除去すること ができれば，THMFP の低減に効果がある。

2) 有機物質を生分解性と吸着性から分類する ことは，最適な高度浄水処理法の選定に有効 であると同時に，処理性能の評価にも極めて 重要であると考えられる.

3) DOC, THM 前駆物質の除去に関して，オゾ ン処理と $\mathrm{O}_{3} / \mathrm{H}_{2} \mathrm{O}_{2}$ 処理では差があることが認 められるため，最適な組合せを検討すること で，処理効率を高められることが判明した。 また，本研究の範囲内では，前段処理にオゾ ン処理, 後段処理に $\mathrm{O}_{3} / \mathrm{H}_{2} \mathrm{O}_{2}$ 処理を行うのが, 最適な組合せであることがわった。

4) 前段 $\mathrm{O}_{3}$ 処理, 後段 $\mathrm{O}_{3} / \mathrm{H}_{2} \mathrm{O}_{2}$ 処理の組合せでは THM 前駆物質, TOC の除去ともに前段の $\mathrm{O}_{3}$ 処理時間を長くした方が効果が高い.

謝辞 : 本研究を行うにあたり, 粒状活性炭を提供 いただいた東京都水道局の方々に厚く感謝の意を 表します。 

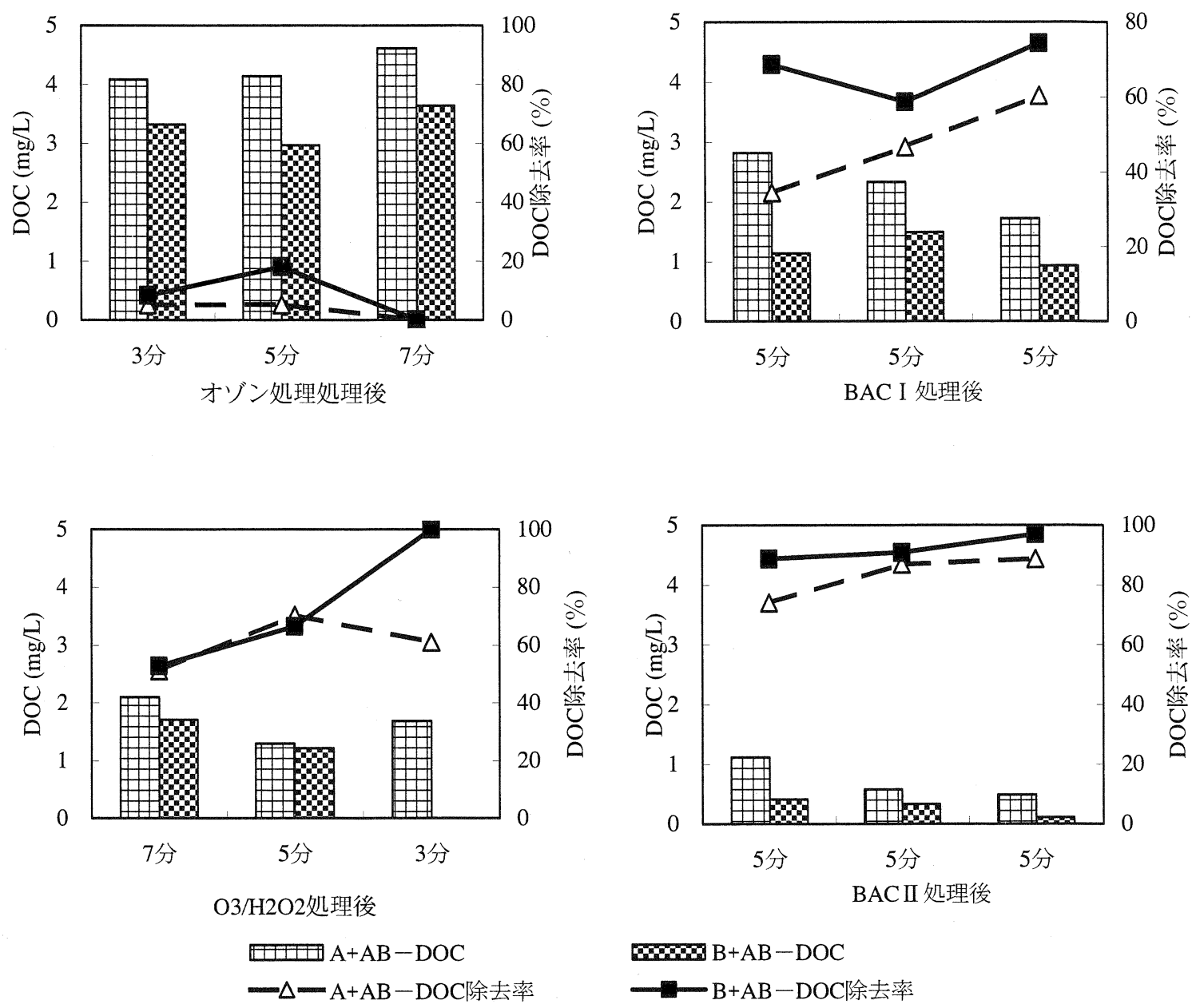

$6 \pi 00 \mathrm{~B}+\mathrm{AB}-\mathrm{DOC}$

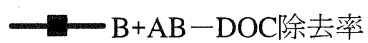

図-10２段処理によるDOCの変化

\section{参考文献}

1) 中川創太: 促進酸化処理装置, 資源環境対策, Vol.39, No.8, pp:84-86, 2003.

2) Cipparone, L.A., Diehl,A.C., and Speitel Jr., G.E.: Ozonation and BDOC removal: effect on water quality, J.AWWA, Vol.89, Issue.2, pp.84-97, 1997.

3）柴田信勝, 茂庭竹生 : 促進酸化法によるフミン・フル ボ酸の無機化特性, 土木学会論文集, No.608/VII-9, pp. 61-75, 1998.

4) 中室克彦, 佐谷戸安好 : 溶存オゾン濃度のアシッド クロムバイオレット K 法による定量に関する研究, 水道協会雑誌, Vol.55, No.10, pp.28-31, 1986.

5) 西嶋 渉, 金 于伉, 正藤英司, 岡田光正: 活性炭に対 する吸着性及び生分解性に基づく溶存有機物の分画, 水道協会雑誌，Vol.65, No.4, pp.25-30, 1996.

6) Acero, J.L.and Von Gunten.U. : Characterization of oxidation processes: Ozonation and the $\mathrm{AOP} \mathrm{O}_{3} / \mathrm{H}_{2} \mathrm{O}_{2}$, J.AWWA, Vol.93, No.10, Page90-100, 2001.

7) Bonnet, M.C., : Removal of Biodegradable Dissolved Organic Carbon in a Water Treatment Plant, Wat.Res.Vol.26, No.12, pp.1673-1680, 1992.

8）茂庭竹生, 岡田光正, 柴田信勝他: 促進酸化法による 有機物の分解に関する基礎実験, 水道協会雑誌, Vol.68, No.10, pp.21-30, 1999.

9) 林 禾, 五味 靖, 茂庭竹生: オゾン及び促進酸化処 理におけるフルボ酸分子量のトリハロメタン生成能 に対する影響水道協会雑誌, Vol.73,No.5,pp.21-3, 2004.

10) Coble, P.G., Green, S.A., Blough, N.V. and Gagosian, R.B. : Characterization of dissolved organic matter in the Black Sea by fluorescence spectroscop, 348, pp.432-435, Nature, 1990. 


\section{IMPROVEMENT OF DOC REMOVAL BY TWO-STAGE TREATMENT OF $\mathrm{O}_{3}$ AND $\mathrm{O}_{3} / \mathrm{H}_{2} \mathrm{O}_{2}$}

\section{He LIN and Takeo MONIWA}

In order to removal of disinfection by-production THM precursor and reduction of TOC, two-stage treatment of ozonation and advance oxidation and BAC treatment were proposed. The result suggest that it was a difference on the removal of the DOC, THM precursor in ozonation and $\mathrm{O}_{3} / \mathrm{H}_{2} \mathrm{O}_{2}$. And it was proven that the treatment effect raised the optimum combination. On the other hand, in the range of this study, it was proven that the $\mathrm{O}_{3} / \mathrm{H}_{2} \mathrm{O}_{2}$ treatment was the optimum combination for the front stage treatment for ozonation. 